BIOTROPIA No. 10, 1997 : $63-74$

\title{
INFLUENCE OF MEDIA GELLING AGENTS ON ROOT BIOMASS AND IN VITRO VA-MYCORRfIZAL SYMBIOSIS OF CARROT WITH GIGASPORA MARGARITA
}

\author{
ALOKADHOLEYA*, ANJALIVERMAand NAVEENPALBHATIA \\ Tata Energy Research Institute, Durban Seth Block, Habitat Place, Lodi Road, New Delhi 110003, India
}

\begin{abstract}
An in vitro study with Ri-TDNA transformed roots of carrot (Daucus carota) was carried out to evaluate the role of macro-elements contributed as impurities in the gelling agent (phytagel) over and above those present in the minimal (M) medium. Production of root biomass was taken as a measure to quantify the influence of macro-elements added to the minimal medium. The levels of phosphorus when adjusted to $1.19 \mathrm{mg} / 1$ and $1.09 \mathrm{mg} / \mathrm{l}$, lead to dry root biomass production at par with the control.

Attempts made to lower the amount of impurities in phytagel by de-ionization using different alkalies, proved $\mathrm{NaOH}$ to give the best results in terms of relatively high amount of root biomass. In an in vitro dual culture system with carrot as host and Gigaspora margarita as the vesicular-arbuscular mycorrhizal fungus, phytagel impurities helped to produce maximum number of infection units and auxiliary cells when phytagel was added to the minimal medium.
\end{abstract}

Key words: Agrobacterium rhiiogenesfDaucus caro/a/Gelling agents/diaspora margarita/Macroelements/Vesicular-arbuscular mycorrhiza/Transformed roots.

\section{INTRODUCTION}

Production of VAM fungi under axenic conditions continues to be one of the most challenging goals of modem biology (Becard and Piche 1992). Mosse and Hepper (1975) were the first to report a simplified in vitro system for the study of VAM development wherein they used excised roots instead of whole plants. Mugnier and Mosse (1987) modified the technique further by using Ri-TDNA transformed hairy roots as the host tissue. Plants with such tumoral roots are potentialy valuable for this kind of study as they not only have exceptionally low nutritional requirements but also allow cultivation on synthetic media axenically (Nuutila et al. 1995).

Amending an appropriate medium for co-cultivating the two components, plant roots and the fungus are the most important factor for a successful vesicular-arbuscular mycorrhizal formation in root organ culture (Becard and Fortin 1988). After the first

*Corresponding author 
report about the M medium (Becard and Fortin 1988), the agar component in this media was replaced by other gelling agents, such as gellen gum (Gel Gro, ICN Biochemicals, USA) or phytagel (Sigma Chemical Co., USA). These gelling agents made the media more transparent, which facilitated observation under the light microscope.

Diop et al. (1992) reported that these gelling agents are polysaccharides with very few impurities. However when analyzed, they were found to contain a number of elemental ions, which significantly increased the concentration of many major and minor ions in the medium. Taking these observations into account, the present study was undertaken to optimize the level of some of the major elements, which are known to help in root growth and eventually improve in vitro culture conditions towards a more stronger symbiosis hi the dual culture system.

\section{MATERIALSAND METHODS}

\section{Transformation of carrot (Daucus carota L.)}

Agrobacterium rhizogenes strain (A4 wild type ATCC 43057) was used to induce transformation (Mugnier and Mosse 1987). A loopfull of overnight grown culture was suspended in MS broth (Murashige and Skoog 1962) (optical density adjusted between 0.6 and 0.7 ). The tap root of carrot was obtained from agricultural fields and was surface sterilized for $10 \mathrm{~min}$. in $30 \% \mathrm{HaOi}$ solution and rinsed three tunes hi sterile, distilled water. The cut ends of roots were then dipped in bacterial suspension for $15 \mathrm{~min}$., filter soaked and put on MS medium supplemented with $500 \mathrm{mg} / 1$ cefotaxime. After about 3-4 weeks, roots emerging from the cut ends were excised and put on MW medium (Becard and Fortin 1988). Healthy white root tips with numerous laterals showing negative geotropism (unlike the non-transformed root cultures) were routinely maintained on $\mathrm{M} 0.2 \%$ medium (w/v) (Becard and Fortin 1988).

\section{Transformation of cucumber (Cucumis sativus $\mathrm{L}_{\text {.) }}$}

Cucumber seeds were surface sterilized as described above and germinated in the dark at $27^{\circ} \mathrm{C}$ on moist, sterile filter paper. When radicles were approximately $2 \mathrm{~cm}$ long, the seedlings were transferred to MS medium slants and kept in growth room at $25^{\circ} \mathrm{C}$ with $16 / 8 \mathrm{~h}$ light/dark photoperiod and a relative humidity of $65 \pm 5 \%$. Once the plants became healthy, sections and slanting incisions were made on stems and leaves. Cut ends were then subjected to transformation. The roots that emerged (showing negative geotropism) were subsequently maintained on $\mathrm{M} 0.2 \%$ medium (w/v). 


\section{Non-transformed root cultures}

Seeds of tomato (Lycopersicon esculentum Mill.), were surface sterilized and the seedlings were put on MS slants. After establishment, healthy roots were excised and placed on MW medium. After 3-4 weeks, they were transferred onto M $0.2 \%$ medium (w/v) and maintained subsequently on the same medium.

\section{Testing host for colonization}

\section{Fungal inoculum}

Azygospores of VAM fungus, Gigaspora margarita Becker and Hall (DAOM 194757, deposited at the Biosystematic Research Center, Ottawa, Canada), grown in pots in a greenhouse, were collected by wet sieving (Gerdmann and Nicolson 1963) and purified by density gradient centrifugation in 60\% urografm (Furlan et al. 1980). Spores thus obtained were then surface sterilized with $2 \%$ chloramine $\mathrm{T}$ and rinsed in antibiotic solution which consisted of $1 \%$ streptomycin and $0.5 \%$ gentamycin (Becard and Fortin 1988). They were then stored on $1 \%$ sterile water agar at $4^{\circ} \mathrm{C}$. Viability of the spores was ascertained visually by their light colour and globule filling. Only viable candidates were picked up and inserted into $1 \%$ sterile water agar and the plates were incubated in a $\mathrm{CO}_{2}$ incubator (Biocenter 2001, Salvis, Switzerland) with $2 \% \mathrm{CO}_{2}$ at $26^{\circ} \mathrm{C}$. Later on, germinated spores were transferred to M medium prepared with $0.4 \%$ (w/v) phytagel.

\section{Selection of host}

For selection of a suitable host for subsequent studies, various root cultures of carrot, tomato, and cucumber were examined for their affinity to in vitro symbiosis with G. margarita. Many of these cultures were developed in our laboratory (except for ERRC-I which was obtained from G. Becard, ERRC, Philadephia. USA) and classified on the basis of rate of root growth, (Table 1) as $\mathrm{A}=$ Fast (root growth $>2 \mathrm{~cm} / \mathrm{day}$ ), $\mathrm{B}=$ Moderate (root growth $1-2 \mathrm{~cm} / \mathrm{day}$ ), and $\mathrm{C}=\mathrm{Slow}$ (root growth $<1 \mathrm{~cm} /$ day). GP-I root culture proved to be one of the fastest growing and besides being $\mathrm{Myc}+$ was selected for subsequent studies.

Table 1. Host species tested for colonization study

\begin{tabular}{|c|c|c|c|}
\hline \multirow[b]{2}{*}{ Species } & \multicolumn{3}{|c|}{ Growth rate } \\
\hline & $\overline{\mathbf{A}}$ & B & $\mathrm{C}$ \\
\hline \multirow[t]{3}{*}{ Carrot } & ERRC-I & & \\
\hline & GP-I & & \\
\hline & GP-II & GP-III & \\
\hline Tomato & Tom & & \\
\hline Cucumber & CU-I & CU-II & cu - IIII \\
\hline
\end{tabular}




\section{Establishment of dual culture}

In vitro dual culture was initiated from a single spore of $G$. margarita and a single healthy root tip. Different root cultures of carrot, tomato and cucumber were used to establish the experimental unit. The petri dishes were kept for incubation in the dark at $26^{\circ} \mathrm{C}$ in order to facilitate the growth of the germ tube (Becard and Piche 1989). The experiment was terminated at the end of 4 weeks. The medium was dissolved and roots were recovered using $10 \mathrm{mM}$ sodium citrate buffer, pH 6 (Doner and Becard 1991). Roots were carefully picked, cleared and stained (Phillips and Hay man 1970). Stained roots were mounted on glass slides and observed at x 200 magnification under compound microscope attached to video camera and image analyser system (Leica, Switzerland) loaded with Quantiment $500^{+}$ software (Leica, Cambridge, UK) having colour option. To get the number of infectious propagule per unit length of root, the number of entry points were divided by total root length.

\section{Root growth and rate limiting factors}

In order to identify the role of certain major nutrient elements such as nitrogen, phosphorus, calcium, magnesium, and sulphur, the basic M medium was modified in different ways (Table 2). The level of each ion was altered while keeping the levels of $j$ other ions constant (Table 3). Both lower and higher concentrations than what is prescribed were tested to study the role of deficiency, alternatively excess availability of the ion selected. Root tip length of carrot GP-I at start of an experimental unit was $2.5 \mathrm{~cm}$ in various treatments. At the end of four weeks, the root system was harvested according to Doner and Becard (1991) and dry weight of the total root system was recorded. The experiment was laid in completely randomised block design and data! were subjected to the analysis of variance (ANOVA) and means were separated using Duncan's multiple range test $(\mathrm{P}<0.01)$.

Table 2. Elemental (ionic) composition of M medium

\begin{tabular}{lccc}
\hline $\begin{array}{l}\text { Elemental ions } \\
\text { selected for the } \\
\text { present study }\end{array}$ & $\begin{array}{c}\text { Levels of elemental } \\
\text { ions contained in } \\
\text { the basic } \mathrm{M} \text { medium } \\
\text { recipe }(\mathrm{mg} / \mathrm{l})\end{array}$ & $\begin{array}{c}\text { Level of ions } \\
\text { contributed by phytagel } \\
\text { in the M medium }(\text { when } \\
\text { added @ } 0.4 \%)(\mathrm{mg} /)\end{array}$ & $\begin{array}{c}\text { Final elemental make } \\
\text { up of the medium (for } \\
\text { selected ions) } \\
(\mathrm{mg} / \mathrm{l})\end{array}$ \\
\hline Nitrogen & 45.86 & $\mathrm{Nj1}$ & 45.86 \\
Phosphorus & 1.09 & 0.40 & 1.49 \\
Calcium & 48.87 & 24.80 & 73.67 \\
Magnesium & 72.15 & 9.20 & 81.35 \\
Sulphur & 95.56 & 1.44 & 97.00 \\
\hline
\end{tabular}


Influence of gelling agents on root biomass and in vitro VA-mycorrhizal symbiosis - Alok Adholeya et al.

Table 3. Levels of selected ions attained with the basic M medium

\begin{tabular}{lccccc}
\hline \hline $\begin{array}{l}\text { Levels of selected } \\
\text { ions (higher and } \\
\text { lower than the M } \\
\text { medium) }\end{array}$ & Nitrogen & Phosphorus & Calcium & Magnesium & Sulphur \\
\cline { 2 - 5 } & & & & \\
\hline Higher levels & 50.86 & - & 83.67 & 96.35 & 107 \\
H2 & - & - & 78.67 & 86.35 & 102 \\
H1 & 40.86 & 1.19 & 68.67 & - & 92 \\
Lower levels & 35.86 & 1.09 & 63.67 & - & - \\
L1 & - & 0.99 & - & - & - \\
L2 & - & 0.89 & - & - & - \\
L3 & - & 0.79 & - & - \\
L4 & - & & & - \\
L5 & & & & \\
\hline
\end{tabular}

\section{Phytagel de-ionization and root growth}

Phytagel was de-ionized by stirring it in distilled and de-ionized water in an Erlenmeyer flask at $60^{\circ} \mathrm{C}$ (Doner and Douds 1995). The requisite amount of mixed bed resin, TMD-8 (Sigma Chemical Co., USA) was then added and the mixture was incubated on a shaker at $60^{\circ} \mathrm{C}$ for four hours. It was then filtered through a clean cheesecloth. To the resultant turbid filtrate $200 \mathrm{mM} \mathrm{KOH}$ solution was added till it became clear $(\mathrm{pH}>8.0)$. This clear filtrate was then poured into pre-chilled iso-propanol and the flakes were recovered by re-filtering it through a cheesecloth and were dried overnight in an oven at $50 \pm 5^{\circ} \mathrm{C}$. The dried de-ionized phytagel was then subjected to ICP-AES (inductiviry coupled plasma-atomic emission spectroscopy) analysis to determine the concentration of ions (Table 4) and to decide subsequently the extent of changes to be made in the ionic composition of elements selected for the present study.

Table 4. ICP-AES analysis of various gelling agents

\begin{tabular}{lcccccccccccc}
\hline \hline $\begin{array}{l}\text { Gelling } \\
\text { Agent }\end{array}$ & $\mathrm{P}$ & $\mathrm{S}$ & $\mathrm{Mg}$ & $\mathrm{Na}$ & $\mathrm{Al}$ & $\mathrm{Pb}$ & $\mathrm{K}$ & $\mathrm{Mn}$ & $\mathrm{Fe}$ & $\mathrm{Ca}$ & $\mathrm{N}$ \\
\cline { 2 - 11 } & \multicolumn{10}{c}{$(\mathrm{mg} / \mathrm{kg})$} \\
\hline Phytagel & 1049 & 394.4 & 2549 & 6789 & 116.8 & $\mathrm{BDL}^{2}$ & 17040 & 26.54 & 96.55 & 7255 & $\mathrm{BDL}^{2}$ \\
EP agar & 37.37 & 3010 & 191.2 & 4150 & 86.07 & $\mathrm{BDL}^{\mathrm{a}}$ & 92.09 & 5.471 & 169.5 & 2635 & $\mathrm{BDL}^{2}$ \\
$\begin{array}{l}\text { De-ionized } \\
\text { phytagel }\end{array}$ & 165.5 & 117.3 & 267.7 & 1850 & 30.43 & $\mathrm{BDL}^{\mathrm{a}}$ & 30398 & 2.133 & 49.35 & 965.7 & $\mathrm{BDL}^{\mathrm{a}}$ \\
\hline
\end{tabular}

${ }^{\mathrm{a}} \mathrm{BDL}=$ Below detectable limit 
Test of de-ionized phytagel with different alkalies was done with an aim to improve rooting. In the routine procedure of phytagel de-ionization $200 \mathrm{mM} \mathrm{KOH}$ is added. This addition increases the $\mathrm{K}$ content of the medium from $135.35 \mathrm{mg} / 1$ to $188.14 \mathrm{mg} / 1$. Since the $\mathrm{K}$ level goes even higher than the impurity level of ordinary phytagel, different alternative alkalies, namely $200 \mathrm{mM} \mathrm{NaOH}, 200 \mathrm{mM} \mathrm{NaHCO} 3,200 \mathrm{mM}$ Trizma and $5 \% \mathrm{NH}_{4} \mathrm{OH}$, were all tested to raise the $\mathrm{pH}$ of the solution. Young, actively growing root tips of carrot (GP-I, $2.5 \mathrm{~cm}$ long) were placed in petri plates, sealed and incubated in the dark at $27^{\circ} \mathrm{C}$. Subsequently, at the end of four weeks, roots were recovered by the method of Doner and Becard (1991) and were dried in a hot air oven at $55 \pm 5^{\circ} \mathrm{C}$ till a constant weight was achieved.

\section{Test of different gelling agents and root colonization}

Because phytagel contains significant amount of elemental impurities (Table 4), various gelling agents namely extra pure (EP) agar $0.7 \%(w / v)$ (Hi Media, India), phytagel $0.4 \%$ $(\mathrm{w} / \mathrm{v})$, de-ionized phytagel $0.5 \%(\mathrm{w} / \mathrm{v})$ and agarose $0.4 \%(\mathrm{w} / \mathrm{v})$ were used to solidify the $\mathrm{M}$ medium. Attempts were made to keep the physical state identical by varying the amount of different gelling agents in the media. In vitro dual cultures were established on these medium using a single spore of G. margarita and carrot GP-I root tip. Auxiliary cells formed after 2 weeks were counted and the experiment was terminated at the end of 4 weeks. After recovering (Doner and Becard 1991) and staining the roots (Phillips and Hay man 1970), the total number of infection units formed under various treatments were counted.

\section{RESULTS AND DISCUSSION}

\section{Amended recipes and root biomass}

An evaluation in terms of dry root weight production $(\mathrm{g})$ for various amended recipes of nitrogen (Fig. la) shows that when the basic M medium recipe was modified, there was a reduction in dry mean root weight of carrot. The percentage reduction over control was highest (50.82) in HI compared to remaining two recipies (L140.86 mg/1 and L235.86 mg/1). As none of the set concentrations performed at par with the control, it is likely that either the reduced levels of nitrogen fail to meet the biochemical and physiological demands of the roots or the disturbances in the $\mathrm{NO}_{3}: \mathrm{NH}_{4}+-\mathrm{N}$ ratio in the medium lowered the recovery of dry root biomass.

In contrast to the basic $\mathrm{M}$ medium recipe, amongst all the five lower levels of phosphorus (P) tested, L1 and L2 recipes were at par with the control while L3, L4 and L5 recipes produced significantly lower root biomass (Fig. 1b). Of all the 
Influence of gelling agents on root biomass and in vitro VA-myconhizal symbiosis - Alok Adholeya et al.

nutrients, insufficiency of $\mathrm{P}$ affects VAM symbiosis the most (Habte and Aziz 1991). It is also well established that high P content is detrimental to VAM establishment and decreases mycorrhizal infection (Abbott and Robson 1977, 1979; Menge et al. 1978) and probably, reduces the uptake of some minor elements namely $\mathrm{Zn}, \mathrm{Fe}$, and $\mathrm{Cu}$. The $\mathrm{M}$ recipe was therefore, modified to incorporate lower levels of $\mathrm{P}$ as, subsequently, there is a need to optimise the $\mathrm{P}$ concentration in the medium for achieving better colonization.

Similarly, out of the four amended recipes for calcium (Table 3) root growth deteriorated to a great extent with $\mathrm{H} 1$ and $\mathrm{H} 2$ recipes (Fig. 1c). Between the other two recipes (L1 and L2) a considerably higher dry root weight was obtained with L1 (percentage reduction over control being 39.96) and a remarkably lower recovery of root biomass was observed in case of L2. Calcium is known to increase the rigidity of plant cell walls by cross-linking protein components by the formation of calcium pectate. $\mathrm{Ca}^{++}$however, could adversely affect the biochemical and physiological processes within the root tissues as calcium at higher concentrations tends to shorten lateral branching in roots (Hirrel 1981) resulting in the low recovery of root biomass and subsequently reducing the uptake of cations like Mg. Lower recovery at L1 and L2 levels could be because of insufficient calcium, which leads to the disorganization of the plasma and vacuolar cell membranes, resulting in increased permeability and subsequent loss of certain vital nutrient ions (Burstrom 1968; Simon 1978).

Amendments carried out in minimal (M) media recipe to achieve two of the higher levels of magnesium, namely $\mathrm{H} 1$ and $\mathrm{H} 2$ produced significantly lower values of dry root biomass (Fig. 1d) when compared with the control. Out of the three different recipes made by amending sulphur in the basic (M) recipe, $\mathrm{H1}$ and $\mathrm{LI}$ recipes produced significantly lower root biomass and were at par while $\mathrm{H} 2$ recorded $77.05 \%$ reduction over control (Fig. le).

Therefore, the original levels of the two elements $\mathrm{Mg}(87.35 \mathrm{mg} / 1)$ and $\mathrm{S}(97 \mathrm{mg} / 1)$ (in $\mathrm{M}$ medium and those added as impurities through phytagel) are optimal to meet the metabolic requirements of young carrot roots in vitro. The reduction in root biomass at higher levels of magnesium may be due to the ionic interactions such as $\mathrm{Ca}^{++}$and $\mathrm{K}^{+}$, resulting in lower availability of this element.

\section{Colonization of roots}

Maximum infection units and auxiliary cells were produced on ordinary phytagel, followed by EP agar, perhaps because certain very important elements present in the phytagel added significantly towards better root growth and symbiosis. A minimum of one infection unit and three auxiliary cells were formed on the medium prepared with de-ionized phytagel, while agarose plates produced the least number of auxiliary cells and infection unit (Table 5). 


\section{BIOTROPIA No 63-74}
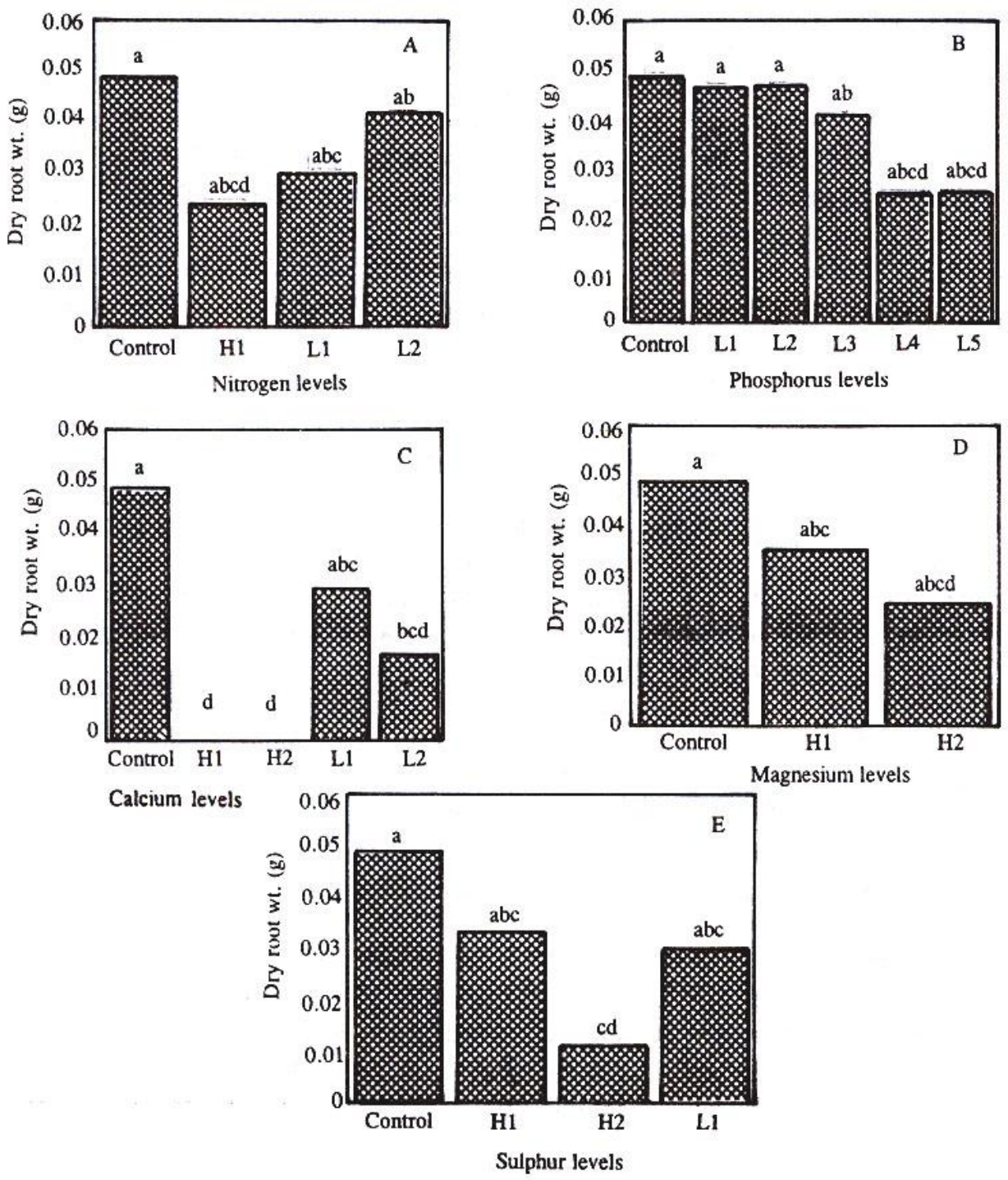

Fig 1. Effect of M medium recipes, amended for various nutrients, on in vitro root biomass. A-E, various recipes amended for nitrogen, phosphorus, calcium, magnesium and sulphur, respectively

Those bars followed by the same letter do not differ significantly by Duncan's multipke range test at $\mathrm{P}<0.01$ 
Table 5. Test of various gelling agents for colonization of Gigaspora margarita

\begin{tabular}{lcc}
\hline \hline Gelling agents & $\begin{array}{c}\text { No. of auxillary cells } \\
\text { (after 2 weeks) }\end{array}$ & $\begin{array}{c}\text { Infection units } \\
\text { (after 4 weeks) }\end{array}$ \\
\hline Extra pure agar & 11 & $10 \mathrm{ab}$ \\
$(0.7 \%)$ & 1 & $0.67 \mathrm{~b}$ \\
Agarose $(0.4 \%)$ & 15 & $20.3 \mathrm{a}$ \\
Phytagel $(0.4 \%)$ & 3 & $1 \mathrm{~b}$ \\
De-ionized & & \\
phytagel $(0.5 \%)$ & & \\
\hline
\end{tabular}

Within the same column, values (an average of 3 replicates) with a different letter are significantly different at $P<0.01$ by analysis of variance.

ICP analysis of EP agar indicates very high sulphur and iron contents compared to phytagel. This could be detrimental to the root growth and colonization. In de-ionized phytagel the level of $\mathrm{K}$ rises significantly, affecting the symbiosis negatively. Agarose $(0.4 \%)$ is devoid of impurities and its water-holding capacity is not as high as that of other gelling agents. Probably, due to this, root growth ceases after some time and affects drastically the colonization process.

\section{Root biomass production in phytagel de-ionized with different alkalies}

The dry root biomass values obtained with phytagel de-ionized by $\mathrm{NaOH}$ and Trizma were highly significant and were at par, while the remaining alkalies tested for de-ionization produced significantly lower root biomass values (Fig. 2). Though sodium is one of the critical components of the medium and the extent of its uptake in plants is sometimes related to the activity of VAM fungi, the level of sodium present in the medium however is quite low $(1.96 \mathrm{mg} / 1)$, therefore, root growth was not adversely affected. Moreover significantly low recovery of root biomass in case of $\mathrm{NaHCO}_{3}$ may be due to increase in level of Na above the critical level.

De-ionization of phytagel with $\mathrm{KOH}$ definitely increases the $\mathrm{K}$ level in the resultant product. $\mathrm{K}^{+}$uptake by any plant is strongly influenced by the form of nitrogen available (whether $\mathrm{NO}_{3}$ or $\mathrm{NH}_{4}{ }^{+}$) as well as by the cations, particularly $\mathrm{Na}^{+}$. It might also be expected to be influenced by the metabolism and polymerization of phosphate (Harley and Smith 1983). Increased $\mathrm{K}^{+}$ concentration in the M medium drastically decreases percent colonization of VAM fungus (Becard and Fortin 1988) and high $\mathrm{K}^{+}$content was also found to be detrimental to root growth (Harley and Smith 1983). De-ionization of phytagel with $\mathrm{NH}_{4} \mathrm{OH}$ also failed to support the root growth. There was no significant difference between $\mathrm{NH}_{4} \mathrm{OH}$ and $\mathrm{NaHCO}_{3}$ treatments. The significant reduction may be due to the fact that excess ammonium 


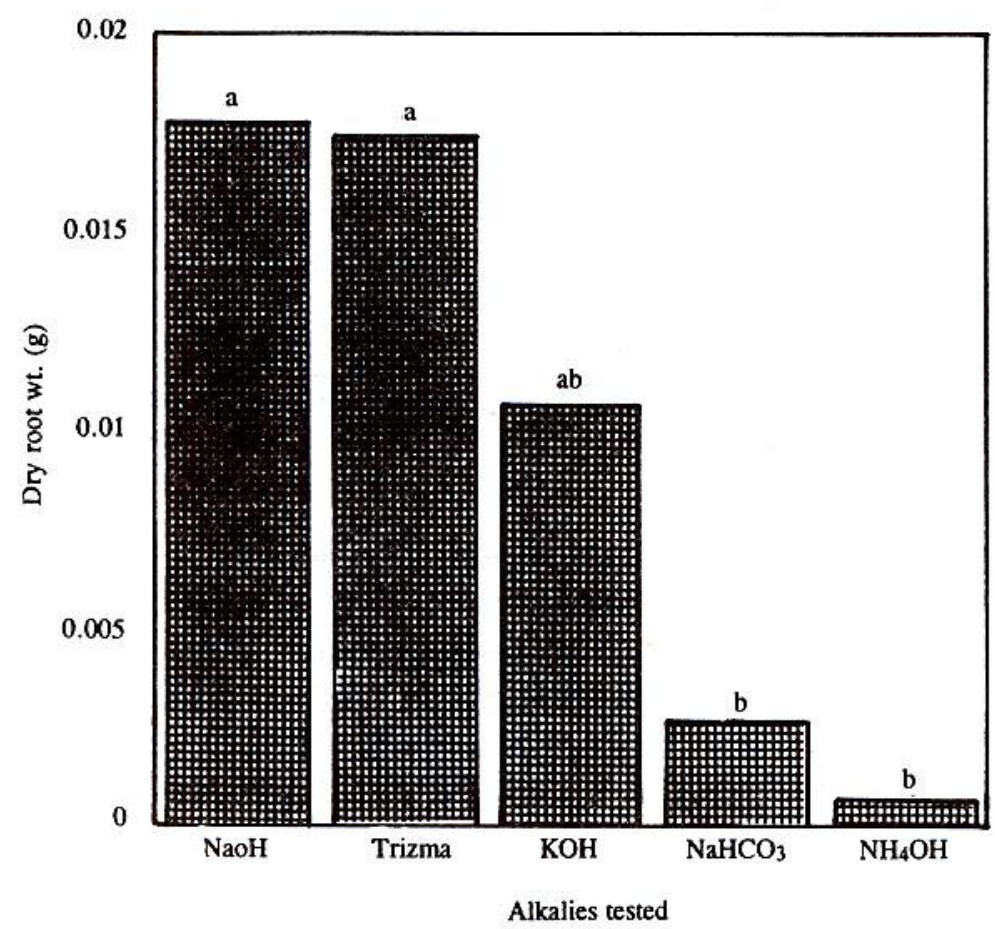

Fig 2. Test of different alkalies for phytagel de-ionization

Those bars followed by the same letter do not differ significantly by Duncan's multiple range test $(\mathbf{P}<0.01)$

ions in $\mathrm{M}$ medium result in a rapid drop in the $\mathrm{pH}$ of the culture medium and is detrimental to root growth (Becard and Piche 1992).

In summary, concentration of major and minor elements, $\mathrm{pH}$, temperature and the biochemical or physiological demands of the tissues of the test species play a critical role in the root growth. A balance must be reached between the requirements of actively growing roots, which need a complex medium, and those of the extra-radical phase of the VAM fungus, which normally grows in a rhizosphere (i.e. in a relatively nutrient-poor medium).

The present study puts forth a major challenge in the task of identifying appropriate nutritional and physiological demands of root cultures and VAM fungus to develop a strong symbiosis. The impurities identified hi "Phytagel" makes the task of identifying an optimal defined medium much more complex. Therefore, there is a need to look for an alternative while defining the requirement for VAM symbiosis. 
Influence of gelling agents on root biomass and in vitro VA-mycorrhizal symbiosis - Alok Adholeya et al.

\section{ACKNOWLEDGEMENTS}

Thanks are due to Mr. Y.P. Kalra for carrying out ICP-AES analysis of various gelling agents and Ms. S. Krishna Sundari for root transformation work. Dr. David Douds and Dr. Sadhna Alstrom made critical comments on an earlier draft of the manuscript, their efforts are thankfully acknowledged. Thanks are due to Director TERI for providing infrastructural support and the Department of Biotechnology Govt. of India, for sponsoring the work carried out under this programme.

\section{REFERENCES}

АВвоTт, L.K. and A.D. ROBSON. 1977. Growth stimulation of subterranean clover with vesicular-arbuscular mycorrhizas. Aust. J. Agric. Res. 28: 639-649.

AввотT, L.K. and A.D. ROBSON. 1979. A quantitative study of the spores and anatomy of mycorrhizas formed by a species of Glomus, with references to its taxonomy. Aus. J. Bot. 27: 363-375.

BAYLEY, J.M., J. KING and O.L. GAMBORG. 1972a. The effect of the source of inorganic nitrogen on growth and enzymes of nitrogen assimilation in soybean and wheat cells in suspension cultures. Planta 105: $15-24$.

BAYLEY. J.M., J. KING and O.L. GAMBORG. 1972b. The ability of amino compounds and conditioned medium to alleviate the reduced nitrogen. Planta 105: 25-32.

BECARD. G. and J.A. FORTIN. 1988. Early events of vesicular-arbuscular mycorrhiza formation on Ri-TDNA transformed roots. New Phytol. 108: 211-218.

BECARD, G. and Y. PICHE. 1989. New aspects on the acquisition of biotrophic status by a vesicular-arbuscular mycorrhizal fungus. Gigaspora margarita. New Phytol. 112: 77-83.

BECARD. G. and Y. PICHE. 1992. Establishment of vesicular- arbuscular mycorrhizae in root organ culture: Review and proposed methodology. In: Methods in Microbiology: Experiments with Mycorrhizae. Varma A.. J.A. Norris, D.J. Read (Eds). Academic Press. New York. p. 89-108.

BURSTROM, H. 1968. Calcium and plant growth. Biol. Rev. 43: 287-316.

DIOP, T.A., G. BECARD and Y. PICHE. 1992. Long term in vitro culture of an endomycorrhizal fungus, Gigaspora margarita, on Ri T-DNA transformed roots of carrot. Symbiosis 12: 249-259.

DONER, L.W. and G. BECARD. 1991. Solubilization of gellan gels by chelation of cations. Biotech. Tech. 5(1): 25-28.

DONER, L.W. and D.D. DOUDS. 1995. Purification of commercial gellan to monovalent cation salts results in acute modification of solution and gel forming properties. Carbohydrate Res. 273: 225-233.

FURLAN, V., H. BARTSCHI and J.A. FORTIN. 1980. Media for density gradient extraction of endomycorrhizal spores. Trans. Br. Mycol. Soc. 75: 336-338.

GERDEMANN, J.W. and T.H. NICOLSON. 1963. Spores of mycorrhizal endogon species extracted from soil by wet sieving and decanting. Trans. Br. Mycol. Soc. 46: 235-244.

HABTE, M. and T. Aziz. 1991. Relative importance of Ca, N, and P in enhancing mycorrhizal activity in Leucaena leucocephala grown in an oxisol subjected to stimulated erosion. J. Plant Nutr. 14(5): 429-442. 
HARLEY, J.L. and S.E. SMITH. 1983. Mycorrhizal Symbiosis. Academic Press Inc., London.

HIRREL, M.C. 1981. The effect of sodium and chloride salts on the germination of Gigaspora margarita. Mycologia 73: 610-617.

MENGE, J.A., D. STERILE, D.J. BAGYARAJ, E.L.V. JOHNSON and R.T. LEONARD. 1978. Phosphorus concentrations in plants responsible for inhibition of mycorrhizal infection. New Phytol. 80: 575-578.

MOSSE, B. and C.M. HEPPER. 1975. Vesicular-arbuscular mycorrhizal infections in root organ cultures. Physiol. PI. Path. 5: $215-223$

MUGNIER, J. and B. MOSSE. 1987. Vesicular-arbuscular mycorrhizal infection in transformed root inducing T-DNA roots grown axenically. Phytopathology 77: 1045-1050.

MURASHIGE, T. and F. SKOOG. 1962. A revised medium for rapid growth and biomass assays with tobacco tissue cultures. Physiol. Plant. 15: 473-497.

NUUTILA, A.M., M. VESTBERG and V. KAUPPINEN. 1995. Infection of hairy roots of strawberry (Fragaria x Ananassa Duch.) with arbuscular-mycorrhizal fungus. PI. Cell Rep. 14: 505-509.

PHILLIPS, J.M. and D.S. HAYMAN. 1970. Improved procedures for clearing roots and staining parasitic and vesicular-arbuscular mycorrhizal fungi for rapid assessment of infection. Trans. Br. My col. Soc. 55: 158-161.

SIMON, E.W. 1978. The symptoms of calcium deficiency in plants. New Phytol. 80: 1-15. 